DOI: $10.21779 / 2077-8155-2017-8-4-61-71$

УДК 297.1+394 А.к. Салмин ${ }^{1}$

\section{Содержание статьи}

\author{
Введение \\ Истоки ислама в Восточной \\ Европе \\ Выбор ислама татарами \\ Ислам среди чувашей \\ Заключение
}

\section{Информация о статье}

Поступила в
28.07 .2017$.
Передана недакцию:
09.08.2017.
Получена рецензия: 24.08 .2017$.
Принята в номер: 25.09 .2017$.

\title{
Исламизация тюрков Поволжья
}

Музей антропологии и этнографии им. Петра Великого (Кунсткамера) РАН; antsalmin@mail.ru

В статье анализируется процесс исламизации тюркских народов Поволжья. Хронологический охват - c VIII в. по сегодняшний день. В контексте имеющихся источников и основной литературы автор пытается выявить способы влияния элементов ислама и кыпчакизмов на чувашей. Прослеживается взаимодействие исламского мира с народными верованиями и православием. При этом до второй половины XIV в. процесс мусульманизации выражен слабо. Основной вывод - ислам и кыпчакские компоненты проникали к чувашам через казанских татар. Обобщения подкрепляются конкретными фактами.

Сегодня ислам среди тюркоязычных народов Среднего Поволжья (татар и мишар) живет и процветает. Он однозначно стал надэтическим и этнообъединяющим фактором. На месте городища Булгар раскинулся исламский культурно-образовательный центр со своим университетом. Историки, религиоведы и этнографы Казани и других городов изучают лучшие традиции ислама. В селе Шыгырданы Батыревского района Чувашской Республики участились встречи, конференции и симпозиумы тюркологов и исламоведов, на которых обсуждают вопросы дальнейшего развития толерантности в межнациональных отношениях. В целом ислам в Поволжье играет положительную роль в сохранении стабильности в важнейшем многонациональном и поликонфессиональном регионе России.

Русские, чуваши, мордва, марийцы, проживающие в регионе дисперсно с татарами и мишарами, исповедующими ислам, видят в своих соседях надежных сограждан.

Ключевые слова: религия, ислам, тюрки, монголь, чуваши.

\footnotetext{
${ }^{1}$ Антон Кириллович Салмин - доктор исторических наук, ведущий научный сотрудник, Музей антропологии и этнографии имени Петра Великого (Кунсткамера) PAH, orcid.org./0000-00021072-9933.
} 
DOI: 10.21779/2077-8155-2017-8-4-61-71

UDC 297.1+394

A.K. Salmin 1

\section{The content of the article}

Introduction.

The origins of Islam in Eastern Europe.

Selecting Islam by Tatars. Islam among the Chuvashes. Conclusion.

\section{Information}

about the article

Received: 28.07.2017.

Submitted for review: 09.08.2017.

Review

received: 24.08.2017.

Accepted for publication: 25.09.2017.

\section{Islamization of Turks of the Volga Region}

\section{Peter the Great Museum of Anthropology and Ethnography (Kunstkamera), RAS;} antsalmin@mail.ru

The article contains an analysis of introduction of Islamic religion among Turkic peoples of the Volga region. Chronologically, it covers the period from the $18^{\text {th }}$ century until now. In the context of the available sources and the basic literature, the author is trying to identify the methods of influence of the Islamic religion elements and kipchakisms on the Chuvash. The interaction of the Islamic world with people's religious faiths and Orthodoxy is discernible. The Muslimization process had been weakly expressed until the second half of the $14^{\text {th }}$ century. The main conclusion is that Islam and Kipchack components were introduced to the Chuvash through Kazanian Tatars. The general conclusions are supported with concrete facts.

Now the Islamic religion is alive and blooming, as the saying goes, among Turkic-speaking people of the Middle Volga (Tatars and Mishars). It clearly has become a super-ethic and ethnounifying factor. At the site of ancient Bulgars' town, an Islamic cultural and education center is spread out with its university. Historians, religious studies scholars, and ethnographers from Kazan and other cities study the best traditions of Islam. Meetings, conferences, and symposia of turkologists and Islam experts held in Shykhyrdany settlement of the Batyrevo District of the Chuvash Republic have become more frequent. They are devoted to the discussion of the matters of further improvement of tolerant attitudes in inter-ethnic relations. In general, Islam plays a positive role in the Volga Region in maintaining stability in the most important multinational and multi-religious region of Russia.

The Russians, the Chuvash, the Mordva, the Mari residing in the region dispersely with Tatars and Mishars who profess Islam see their neighbors as faithful fellow citizens.

Keywords: religion, Islam, Turks, Mongols, Chuvash.

\section{Введение}

Этнические составляющие - признаки непостоянные. Смена культурообразующих компонентов помогает им преобразовываться, преодолевать кризисы и способствует возрождению. Перерождаются народы в самом широком смысле. Тюркомонгольские племена, то объединяясь, то распадаясь на орды, то вовлекая в свои воинские соединения покоренные племена, смогли завоевывать степи. Так исчезали одни народы и возникали другие. В статье анализируется взаимодействие исламского движения с контактными культурами на примере тюркских народов Поволжья.

\footnotetext{
${ }^{1}$ Anton Kirillovich Salmin - Dr. Sc. (History), leading researcher at RAS Peter the Great Museum of Anthropology and Ethnography (Kunstkamera), orcid.org/0000-0002-1072-9933.
} 


\section{Истоки ислама в Восточной Европе}

В VIII-X вв. в Восточной Европе происходят изменения в религиозной ситуации. Хазары принимают иудаизм, булгары - ислам, русские - православие. Однако говорить о древних корнях ислама среди тюркских племен не приходится. Считается, что первым тюркским правителем, принявшим ислам как государственную религию, стал Абд ал-Карим Сатук Бугра-хан (901-955 гг.), основавший Караханидскую державу в Средней Азии. Именно после него исламизация тюрков принимает не только массовый, но и стремительный характер. Теперь у большинства тюркских народов мира цементирующим, этнообъединяющим фактором (на уровне как общества, так и семьи) становится религия.

K XI-XIII вв. христианство сохраняется в западной части Восточной Европы, ислам представлен в Волго-Камье, а древняя религия - в Куманской степи. Источник начала XIII в. констатировал, что башкиры (басджирты) - безбожники [9, с. 34]. Однако Ибн-Фадлан еще в начале X в. заметил, что в его посольстве служил башкир, уже принявший ислам [13]. Иначе говоря, башкиры ни в X, ни в XIII веке в основном еще не были исламизированы, как и подавляющее большинство населения Поволжья. С приходом монголов начинается конкуренция между православием и исламом за влияние на номадов и на оседлое население, ведущее старинный образ жизни.

Бату - сын Туши и внук Чингиз-хана, получил престол из рук Чингиз-хана (12081246 гг.). «Под его власть подпали все земли племен Туркестана (начиная) от Хорезма, булгар, буртасов и саклабов до пределов Рума» [1, с. 15]. Источник сообщает, чтоБату был человеком справедливым и другом мусульман. При нем мусульмане вели привольный образ жизни. В лагере и на землях подчиненных племен были построены мечети, в них имелись имамы и муэдзины. Знающие люди говорили, что сам Бату втайне стал мусульманином и скрывал это. Похоронили его по монгольскому обычаю (устройство большой ниши под землей, обеспечение дорогими вещами, сопровождение близкими людьми, сокрытие места захоронения путем прогона лошадей на месте могилы). В описаниях Плано Карпини от 1246 г. монголо-татары в ставке Бату-хана представлены еще почти классическими приверженцами своих древних традиций. Они имели антропоморфные куклы из войлока, которых помещали с обеих сторон дверей ставки. В их представлениях такие фигуры охраняли стада, обеспечивали обилие молока и приплод скота. Другие фигурки делали из шелка и весьма их почитали. Помещали их на прекрасно оформленных повозках перед входом в ставку. На изготовление таких кукол собирались все пожилые хозяйки, закалывали овцу и сжигали кости. Над ложем больных людей прикрепляли такие же куклы. Своим божествам монголо-татары приносили молоко, а также часть своих кушаний. А по возвращении с охоты им посвящали сердце зверя. Они также поклонялись солнцу, луне, огню, воде и земле. Глубоко верили в пр одолжение жизни в ином мире [4, с. 35-36].

Имеется описание Гильома де Рубрука крымских татар в 1253 г. Их традиции были во многом схожи с религиозным поведением татар в целом. Отмечается, что дом делится на мужскую и женскую части. Мужская часть находилась на северной стороне. Хозяин сидел на своей постели лицом к югу. Над изголовьем кровати были прибиты войлочные куклы: у мужчин - в виде кобыл, у женщин - в виде коров. Назывались они сторожами дома. Всякий раз перед питьем эти изображения обрызгивали напитком [18, c. 93].

Берке-хан - сын Джучи (Туши), внук Чингиз-хана, вступил на престол Северного царства в 652 г. х. (1254-1255 гг.). Еще при рождении отец его сказал: «Этого сына я делаю мусульманином, добудьте ему мусульманскую кормилицу, чтобы она его пупо- 
вину обрезала по-мусульмански и чтобы он пил мусульманское молоко, ибо этот сын мой будет мусульманином» [1, с. 16]. Был выбран и имам для обучения его Корану. Потом совершили обряд обрезания над ним. А по достижении возмужалости в его войско передали всех мусульман из стана отца (из земель саксинских, булгарских и саклабских). Став взрослым, он посетил Бухару и встретился с мусульманскими учеными. Затем отправил доверенных людей к халифу, был облачен в почетные одежды, присланные халифом.

Согласно мамлюкским источникам, проблемы с Хулагу вынуждают его развязать войну и поднять ислам до уровня государственной религии. С этой целью он меняет своих администраторов на хорезмских. Следует учесть, что и сам Берке по материнской линии происходит из Хорезмшахов [21, с. 112]. В его стане была установлена пятничная молитва. Каждый всадник в его войске имел молитвенный коврик и совершал намаз. Воины не пили вина, при них находились ученые и толкователи Корана. Во дворце Берке-хана происходили диспуты относительно шариата. Так Берке стал первым ханом, кто официально принял ислам. Это было поворотным пунктом в распространении ислама среди номадов Восточной Европы. Он сам «сделался мусульманином и заставил принять ислам татар, находящихся в его государстве» [4, с. 121]. Берке-хан также выступил против неверного Хулаку и нанес ему поражение. На его сторону в защиту мусульманской религии встали татары северных областей. «Он воздвиг маяк веры и установил обряды мусульманские, оказывал почет правоведам, приблизил их к себе, держал их вблизи от себя, сдружился с ними, и построил в пределах своего государства мечети и школы» [23, с. 151]. За ним последовал и его народ. Его жена Джиджек хатун также стала мусульманкой. Она построила себе мечеть из шатров и возила ее с собой. В 661 г. х. (1262-1263 гг.) Берке-хан известил царя стран Египетских и Сирийских, что Аллах облагодетельствовал его исламом. Султан поздравил его и отправил весьма дорогие подарки (Священное Писание, ковры для молитвы, одежды левантские, мечи, булавы золоченые). Берке-хан создал в землях Дештских лучшие условия для развития ислама. Он пригласил к себе ученых и шейхов со всех краев, раздал им богатые подарки [7, с. 461].

После Берке в 665 г.х. (1266-1267 гг.) вступил на престол в Сарае сын его брата Менгу Темир. Его также поздравил сам султан. Заодно султан намекнул, что было бы хорошо выступить против неверного Абаги, сына Хулаку. На сторону мусульманской религии встал и Ногай-хан со своим народом. Султан поспешил написать Ногаю обильное признание и призвал возбудить священную войну против неверующих. К Менгу Темиру перешло господство над Северными, Тюркскими, Кыпчакскими странами, а также над Железными Воротами. После Менгу Темира в 681 г.х. (1282-1283 гг.) на престол вступил Туданменгу. Он также отправил посольство к султану с известием о принятии ислама. Султан известил о своей радости [23, с. 152-153; 4, с. 121-122].

При поддержке сторонников ислама в 1313 г. воцарился Узбек-хан. В 720 г. х. (1320-1321 гг.) он сам принял ислам, казнил глав ордынской аристократии, не принявших новую религию. Ислам стал религией большинства кыпчаков. Суфии и купцыпрозелиты Средней Волги и Средней Азии получили покровительство чингизидской администрации на государственном уровне. Так ислам стал мощным идеологическим оружием кочевников, обращенных в новую веру, против своих же сородичей и соседей, оставшихся в стороне от мировой религии [6, с. 329, 333]. Но после падения Золотой Орды ислам смог удержаться только на Средней Волге и в Крыму. 


\section{Выбор ислама татарами}

Еще в 30-50-х гг. XV в. большинство татар жили по дедовским традициям - они также возили антропоморфные куклы на своих телегах, придерживались культа некоторых животных («имеют обычай поклоняться каждый день какому-нибудь животному, встреченному ими при первом выходе из дома» [3, с. 159]). На окраинах мусульманского мира появление прозелитов относится к началу XIX в. Например, до начала XIX в. большинство барабинских татар соблюдали древние обряды и верования.

Образование Золотой Орды, а затем и Казанского ханства возродило города. Вместе с городами возродилось и магометанство. Оно объединило татар - бывших булгар жителей городов Волжской Булгарии. Как считают исследователи, в период Казанского ханства булгары-мусульмане полностью окыпчакились, этноним булгар начинает заменяться термином mamapbl. B XV-XVI вв. жившие на территории Казанского ханства марийцы, удмурты и чуваши подвергались влиянию ислама. По данным на вторую половину XVIII в., «многие чуваши по обыкновению татар брили головы, были охотниками до конины, а некоторые свиней не держали» [16, с. 11, 22]. Сельской массе, жившей по родовым традициям, приходилось туго. Исчезали целые поколения нетатарского люда. Принятие ислама для них всегда означало ассимиляцию в татарской этнической среде.

В период Казанского ханства среди чувашей были распространены новые административные порядки. Церемонии ханского двора чуваши переносили на свои божества, которых они стали представлять в виде важного хана и разных чиновников, окружающих, сопровождающих и прислуживающих ему. Например: Тӑвам ырӑ «Божество, заседающее в диване», Хум керрекес̧ӗ «Кравчий хана», Тӑвам с̧йретекен «Божество, ведающее делами дивана», Мӑн турра алӑк ус̧акан «Отворяющий двери жилища» и т. д. Эти явления явно отражают торжественную обстановку ханского двора. Празднование пятницы, перенятое из ислама, также сохранялось среди чувашей долго. Процесс исламизации среди чувашей шел интенсивно. При этом следы исконного прошлого проявлялись весьма скудно. Так, в документе от 1673 г. говорится, что в деревне Ачей Зюрейской дороги ясачные татары похоронили мертвых чувашей 3 человека [13, с. 90]. Из контекста видно, что и сами участники похоронной процессии были вчерашними чувашами, недавно принявшими ислам и превратившимися в татар.

Исследователи похоронно-поминальной обрядности чувашей обращают внимание на эпизод под названием «Мост для покойного». Речь идет о символическом мостике между деревней и кладбищем. Его следует перейти душе умершего родственника. Исследователи сравнивают мостик с авестийским мостом-разделителем. Однако такой мост в исламе называютсират [2, с. 297]. Расположен он над огненной преисподней. Такой мост тоньше волоса и острее лезвия меча. Как правило, вступающие на него праведные души проходят в рай, а грешные - в ад.

С точки зрения средневековых чувашей и чувашей Нового и Новейшего времен, тюрки символизируют исламскую культуру. Начиная с XIV в. ислам стал государственной религией на огромной территории, завоеванной монголами. Крымское, Казанское, Астраханское, Казахское, Узбекское ханства стали сугубо мусульманскими. Парадокс истории в том, что завоевателями земель стали монголы, а религия на этих землях утвердилась исламская. В это непростое время часть предков чувашей сумела сохранить свои традиционные обряды и верования. Однако плохой уровень изученности (вернее - неизученность) системы традиционных обрядов и верований предков современных чувашей стала причиной обращения к древнетюркской мифологии с целью 
«старения» истории булгар, суваров и савиров. Например, вместо того чтобы хорошо

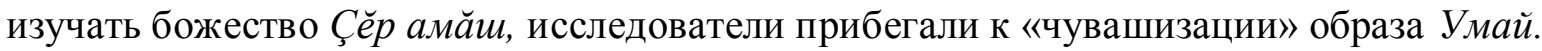

C середины XVIII в. православие в Поволжье осуществляет свою наступательную миссионерскую деятельность. Татарское духовенство в ответ начинает «усиленно насаждать в народе исламистские обычаи и бытовые формы, чтобы этим резче отделить татар от соседей, особенно от русских, изолировать татарскую массу и сохранить свое преимущественное влияние на нее» [5, с. 76].

\section{Ислам среди чувашей}

Исламизацию чувашей можно проиллюстрировать на истории ряда деревень. Для примера возьмем деревню Артемьевку Оренбургской области. У этого населенного пункта имеется и татарское название - Булантамак. Артемьевка окружена татарскими деревнями. У чувашей этой деревни с татарами существуют тесные экономические связи. Как и везде, жители Артемьевки никогда серьезно не занимались торговлей и ремесленничеством. Их занятие - земледелие. В то же время чуваши пользовались услугами татар - портных, валяльщиков, сапожников, красильщиков, мелких торговцев, пастухов. Малоземельные чуваши брали у татар в аренду землю. Все это позволяло татарам вести повседневную пропаганду среди чувашей с целью обращения их в ислам. При этом использовали тон назидания, не оставляющий места возражениям. Татары всячески унижали православие и древнюю веру чувашей. Первые сдвиги в сознании чувашей в пользу ислама в Артемьевке начали происходить в $80-$-х гг. XIX в. [10, с. 697-700]. А после царского указа от 1905 г. о религиозной реформе чуваши этой и других местностей начинают повально принимать ислам. Сначала они сдают свою веру, потом начинают одеваться как татары, затем начинают говорить по-татарски. Все эти сдвиги подкрепляются строительством мечетей и обучением в школах на татарском языке.

Тема особенно хорошо иллюстрируется на примере Буинского и Симбирского уездов. Многие чуваши этих местностей не только перешли в ислам, но de facto и стали татарами. В их числе деревни Буинка, Сиушево, Чепкасы, Ильметево, Чакилдым, Дуваново, Шаймурзино и с. Трехбалтаево. Деревня Буинка отатарилась совсем, а остальные - частично или наполовину. Бывали случаи, что чуваши в таких населенных пунктах возбуждали ходатайство об отделении от татар в административном и земельном отношениях [17, с. 142-143]. Однако все эти старания не воплощались в жизнь.

Об исламизации чувашей и ее роли в трансформации этничности чувашей имеется целый ряд публикаций. Активно работают в этом направлении Е.А. Ягафова, T.В. Семенова и Дурмыш Арык. В частности, они считают, что татары, под чьим влиянием находились и находятся чуваши, понуждают их идентифицировать себя татарами. К тому же в письменных источниках мусульманизированных чувашей определяли как татар. Чуваши, придерживающиеся своих традиций, также подпадали под влияние исламской культуры. Это влияние можно увидеть в их обрядах, религиозной практике и терминологии. В ряде селений Урало-Поволжья исламизация завершилась полной ассимиляцией чувашей и привела к появлению целой группы янга мусулмэнлар «новых мусульман» с татарским языком и этническим самосознанием $[24$, с. $11-15 ; 20 ; 25$, c. 37-54].

Что касается башкир, то они придерживались своих старинных традиций дольше, чем татары. На конец XVII в., например, имеется такое наблюдение: верования их большей частью древние, хотя часть склоняется к магометанству [11, с. 277]. Ислам и восточные влияния среди татарского и башкирского населения долгое время развива- 
лись в целом в среде городского населения, интеллигенции и зажиточных крестьян. В сельской местности еще сохранялись древние молитвенные рощи.

У башкир зафиксировано огромное количество прямых совпадений с народными обрядами, мифологическими персонажами и другими традиционными предметами и представлениями чувашей [22; 19]. Например, персонажи: Ай - Уйӑх «Луна», Aльлn Улӑп «Исполин», Бисура - Пичура «Кикимора», Ел - Сһил «Ветер», Елмауз - Йӗлмевӗс «Вампир», Эйэ - Ийе «Хозяин бани». Из области представлений о времени можно привести ахыр заман - ахӑр саман «светопреставление, конец света». Мифологическое дерево байтирек (букв. «богатое дерево», точнее - тополь) отразилось в чувашском названии деревни Патирек. Из женских украшений: дәуәт - тевет «перевязь, украшенная монетами». Также имеются одинаковые заимствования из персидской (Аждаһa Açтаха «змея Аждаха») и арабской (Кирәмәт - Киремет «Чудо») мифологий.

Религиозная жизнь мусульманского мира Симбирской и Казанской губерний имеет специфические черты. Специфичность выражается прежде всего в толерантности, взаимном уважении этнических культур, их взаимопроникновении. Все эти положительные стороны религий (как официальных, так и этничных) в Поволжье проявились еще в Средневековье. Беда в том, что они мало, плохо или вовсе не раскрыты. Следует отметить, что уход чувашей в ислам, в частности, проходил в знак протеста против насильственного крещения. Верно и утверждение, согласно которому чуваши Правобережья также не остались вне влияния мусульманства. «Но в общей религиозной структуре чувашей данного региона мусульманское влияние носило лишь поверхностный характер, оно не изменило коренной сущности их ранних представлений и культа. Такой тип религиозного синкретизма можно условно назвать “языческо-мусульманским”, где домусульманский элемент оставался господствующим» [15, с. 65].

Как видим, начиная с X, а особенно с ХІІІв., влияние ислама на чувашей велико. Оно имеет и положительные аспекты. Исламизация позволила чувашам сохранить островки населенных пунктов, придерживающихся своей исконной религии, а не раствориться в православии. Но это был бытовой ислам. При первой же возможности чуваши, «принявшие» ислам, возвращались к своим традициям. Например, жители д. Байбахтино Буинского уезда в годы реакции после 1905 г. вынуждены были для вида перейти в ислам. «Как наступила революция в России, байбахтинцы оставили магометанство и вновь объявились чувашами-язычниками, каковыми являются по настоящее время», писал в 30-х годах ХХ в. исследователь К.В. Элле [12, с. 14]. То же самое можно сказать о чувашах Самарской и Ульяновской областей и Татарстана.

\section{Заключение}

Раскопки могильников кочевников второй половины XIV в. на бывшей территории Булгарского улуса Золотой Орды проводились в основном у города Булгар и рядом с городом Джукетау. Большая часть памятников расположена по периметру Куйбышевского водохранилища. Подавляющее большинство этих кладбищ принадлежит населению с традиционным (древним) верованием. Захоронения по обряду, близкому к мусульманскому, составляют не более 13 \%. Все они принадлежат единому этнокультурному комплексу кыпчакского населения. Но следует отметить интеграцию кыпчаков с местным населением. Процесс мусульманизации выражен слабо. Многие села поволжских татар еще к концу XIX в. имели по два-три кладбища. Те, которые называют «старыми кладбищами», относятся к доисламскому времени. Отличительными признаками являются вещи, находимые в могилах, ибо мусульмане этого не делают. 
Следует учесть мощный монголо-татарский пласт в формировании казанских татар. Признавая историческую правомерность булгарского субстрата, не надо забывать о золотоордынско-тюркском компоненте. Такая ошибка в исследованиях происходит в значительной мере в результате некомплексного анализа источников. Существующие видения формирования волго-уральских татар («булгаристская» и «татаристская») являются односторонними из-за своих крайностей: в первом случае обнаруживается недооценка золотоордынско-тюркских, а во втором - дозолотоордынских составляющих татар. Слияние булгаро-мусульман с пришлыми золотоордынскими кыпчаками, смешение этих двух разных групп этносов на физическом, языковом и культурном уровнях приобрели активный характер. А это привело в XV в. к формированию на левобережье Волги народности «казанские татары».

Кыпчакские слова, имеющиеся в чувашском языке, проникли не непосредственно от самих кыпчаков, а через казанских татар. В основном в период Казанского ханства, когда все административные должности занимали татары, назначенные тарханами чуваши играли второстепенную роль в управлении. Доверие к ним могло быть только при принятии ими исламской веры. Даже многие населенные пункты получили названия от имен татарских наместников: Шималахи < шейх Амалах, Шибулатово < шейх Булат, Янситово < Ян Сеит и т. д. Целые селения переходили в мусульманство и отатаривались. Таким образом, в Арском районе не осталось ни одного чувашского селения.

В XVII в. в Казанском уезде многие чуваши приняли ислам и начали именовать себя татарами. Так, по состоянию на 1673 г. в д. Ачи Зюрейской дороги Казанского уезда жили ясачные татары. Но своими родителями (отцами идедами) они называли ясачных чувашей этой же деревни.

\section{Литература}

1. Ал-Джузджани. Насировы разряды // Сборник материалов, относящихся к истории Золотой Орды. - Т. ІІ. - М.; Л.: Изд-во АН СССР, 1941. - С. 13-19.

2. .Али-заде A.A. Исламский энциклопедический словарь. - М.: Ансар, 2007. $400 \mathrm{c}$.

3. Барбаро Иосафат. Путешествие в Тану // Барбаро и Контарини о России: к истории итало-русских связей в XV в. - Л.: Наука, 1976. - С. 136-187.

4. Бейбарс Рукнеддин. Сливки размышления по части летописания гиджры: сборник материалов, относящихся к истории Золотой Орды. - Т. І. - СПб.: С.Г. Строганов, 1884. - C. $83-123$.

5. Воробъев Н.И. Происхождение казанских татар по данным этнографии // Происхождение казанских татар. - Казань: Татгосиздат, 1948. - С. 62-80.

6. Голден П.Б. Религия кыпчаков Средневековой Евразии // Степи Евразии в эпоху средневековья. - Т. 6. - Донецк: ДНУ, 2008. - С. 309-340.

7. Ибн-Араб Шах. Чудеса предопределения в судьбах Тимура: сборник материалов, относящихся к истории Золотой Орды. - Т. І. - СПб.: С.Г. Строганов, 1884. - С. $455-$ 474.

8. Ибн Са'ид ал-Магриби. Книга распространения земли в длину и ширину // Коновалова И.Г. Восточная Европа в сочинениях арабских географов XIII-XIV вв.: Текст. Перевод. Комментарий. - М.: Восточ. лит., 2009. - С. 19-75.

9. Ибн-Фадлан. Книга // Ковалевский А.П. Книга Ахмеда Ибн-Фадлана о его путешествии на Волгу в 921-922 гг. Ст., пер. и коммент. - Харьков: Харьков. ун-т, 1956. - С. $119-148$. 
10. Иванов А. Царство ислама среди чувашей // Самарские епархиальные ведомости. - 1907. - № 19 (1 октября). - С. 697-707.

11. Идес Избрант и Бранд Адам. Записки о русском посольстве в Китай (16921695). - М.: Гл. ред. вост. лит., 1967. - 404 с.

12. Архив Института истории материальной культуры РАН. Ф. 2.ОП. 2.

13. Исхаков Д.М. От средневековых татар к татарам Нового времени (этнополитический взгляд на историю волго-уральских татар XV-XVII вв.). - Казань: Мастер Лайн, 1998. - $276 \mathrm{c.}$

14. Карпини Джсванни дель Плано. История монгалов // Карпини Джованни дель Плано. История монгалов; Рубрук Гильом де. Путешествие в Восточные страны; Поло Марко. Книга. - М.: Мысль, 1997.

15. Кудряшов Г.Е. Динамика полисинкретической религиозности. - Чебоксары: Чуваш. кн. изд-во, 1974. - 356 с.

16. Миллер Г.Ф. Описание живущих в Казанской губернии языческих народов, яко то черемис, чуваш и вотяков. - СПб.: Имп. АН, 1791. - VIII, 99, IIc.: 8 л. ил.

17. Прокопьев $K$. Влияние татар-мусульман начуваш // Чичерина $C$. У Приволжских инородцев: путевые заметки. - СПб.: Тип. В.Я. Мильштейна, 1905. - С. 142-145.

18. Рубрук Гильом де. Путешествие в Восточные страны // Карпини Джованни дель Плано. История монгалов. - М.: Мысль, 1997. - С. 88-189.

19. Салмин А.К. Праздники, обряды и верования чувашского народа / науч. ред. чл.кор. РАН С.А. Арутюнов. - Чебоксары: Чуваш. кн. изд-во, 2016. - 688 с., ил.

20. Семенова T.B. Обрядовый календарь чувашей в этноконтактных с татарами районах. - СПб.: ЛЕМА, 2015. - 145 с.

21. Фаверо-Думенжу М. Первое письмо хана Берке султану Бейбарсу по мамлюкским источникам (661/1263 г.) // Золотоордынская цивилизация. - Вып. 4. - Казань: ИИ AH PT, 2011. - C. 101-113.

22. Хисамитдинова Ф.Г. Мифологический словарь башкирского языка. - М.: Наука, 2010. $-455 \mathrm{c}$.

23. Эннувейри Шихабеддин. Краткий предел необходимости по части науки благовоспитанности: сборник материалов, относящихся к истории Золотой Орды. - Т. I. СПб.: С.Г. Строганов, 1884. - С. 128-171.

24. Ягафова E.A. Религиозные практики этноконфессиональных групп чувашей // Этнографическое обозрение. - 2015. - № 5. - С. 3-18.

25. Arik Durmus. Islam among the Chuvashes and its Role in the Change of Chuvash Ethnicity // Journal of Muslim Minority Affairs. - 2007. - Vol. 27. - № 1. - P. 37-54.

\section{References}

1. Al-Dzhuzdzhani. Nasirovy razryady [Tabaqat-i Naziri] Sbornik materialov, otnosyashchikhsya $k$ istorii Zolotoi Ordy [Collection of Materials Relating to the History of the Golden Horde]. V. II. Moscow-Leningrad: Izd-vo AN SSSR, 1941. - S. 13-19. (In Russian)

2. Ali-zade A.A. Islamskii entsiklopedicheskii slovar [Islamic Encyclopedia]. Moscow: Ansar, 2007. - 400 s. (In Russian)

3. Barbaro Iosafat. Puteshestviye v Tanu [Journey to Tanu] Barbaro $i$ Kontarini o Rossii: $K$ istorii italo-russkikh svyazei v XV v. [Barbaro and Contarini on Russia: the History of the Italian-Russian Ties in the $15^{\text {th }}$ Century]. Leningrad: Nauka, 1976. - S. 136-187. (In Russian) 
4. Beibars Rukneddin. Slivki razmyshleniya po chasti letopisaniya ghidzhry [The Finest of the Reflections on the Gidzhry Chronicle] Sbornik materialov, otnosyashchikhsya $k$ istorii Zolotoi Ordy [Collection of Materials Relating to the History of the Golden Horde].V. I. Saint Petersburg: S.G. Stroganov, 1884. - S. 83-123. (In Russian)

5. Vorob'yev N.I. Proiskhozhdeniye kazanskikh tatar po dannym etnografii [The Origins of Kazan Tatars according to Ethnography] Proiskhozhdeniye kazanskikh tatar [The origins of Kazan Tatars]. Kazan: Tatgosizdat, 1948. - S. 62-80. (In Russian)

6. Golden P.B. Relighiya kypchakov srednevekovoi Yevrazii [The Religion of the Cumans in the Medieval Eurasia] Stepi Yevrazii v epokhu srednevekov'ya [Eurasian Steppes in the Middle Ages]. V. 6. Donetsk: DNU, 2008. - S. 309-340. (In Russian)

7. Ibn-Arab Shakh. Chudesa predopredeleniya v sud'bakh Timura [The Acts of God in the Fate and Fortunes of Timur] Sbornik materialov, otnosyashchikhsya k istorii Zolotoi Ordy [Collection of Materials Relating to the History of the Golden Horde].V. I. -Saint Petersburg: S.G. Stroganov, 1884. - S. 455-474. (In Russian)

8. Ibn Sa'id al-Magribi.Kniga rasprostraneniya zemli v dlinu i shyrinu [The Book of Spreading the Land in Length and Breadth] Konovalova I.G. Vostochnaya Yevropa $v$ sochineniyakh arabskikh gheografov XIII-XIV vv.: Tekst.Perevod. Kommentarii [Eastern Europe in the Writings of Arab Geographers of the $13^{\text {th }}-14^{\text {th }}$ Centuries]. Moscow: Vostoch. lit., 2009. - S. 19-75. (In Russian)

9. Ibn-Fadlan. Kniga [The Book] Akhmeda Ibn-Fadlana o yegoputeshestvii na Volgu $v$ 921-922 gg. St., per. i komment [Akhmed Ibn Fadlan's Book about His Journey to the Volga River in 921-922]. Khar'kov: Khar'kov. un-t, 1956. - S. 119-148. (In Russian)

10. Ivanov A. Tsarstvo islama sredi chuvash [The Kingdom of Islam among the Chuvash] Samarskiye yeparkhial'nyye vedomosti [Samara Eparchial Gazette]. 1907. - S. 697707. (In Russian)

11. Ides Izbrant $i$ Brand Adam. Zapiski o russkom posol'stve v Kitai (1692-1695) [Notes on the Russian Embassy in China (1692-1695)]. Moscow: Gl. red. vostoch. lit., 1967. - 404 s. (In Russian)

12. IIMK (arkhiv Instituta istorii material'noi kul'tury RAN).F. 2.Op. 2.1453 - Elle K.V. Drevnosti Chuvashskoi ASSR [The Antiquities of the Chuvash ASSR]. 1934 g. - 261. (In Russian)

13. Iskhakov D.M. Ot srednevekovykh tatar $k$ tataram novogo vremeni (etnopoliticheskii vzglyad na istoriyu volgo-ural'skikh tatar XV-XVII vv.)[From the Medieval Tatars to the Tatars of the Modern Times (Ethno-Political Insights in the History of the Volga-Ural Tatars in the $15^{\text {th }}-17^{\text {th }}$ Centuries)]. Kazan: Master Lain, 1998. - 276 s. (In Russian)

14. Karpini Dzhovanni del' Plano. Istoriya mongalov [History of the Mongals] Karpini Dzhovanni del' Plano. Istoriya mongalov [History of the Mongals]; Rubruk Ghil'om de. Puteshestviye $v$ Vostochnyye strany [Journey to the East]; Polo Marko. Kniga [Book]. Moscow: Mysl', 1997. - S. 29-85, 381-393. (In Russian)

15. Kudryashov G.Ye. Dinamika polisinkreticheskoi relighioznosti [The Dynamics of Political Religiosity]. Cheboksary: Chuvash. kn. izd-vo, 1974. - 356 s. (In Russian)

16. Miller G.F. Opisaniye zhyvushchikh v Kazanskoi gubernii yazycheskikh narodov, yako to cheremis, chuvash $i$ votyakov [The Description of Pagan Peoples - the Cheremis, the Chuvash and the Udmurts - living in Kazan Province]. SPb.: Imp. AN, 1791. - VIII, 99, II s.: 81. il. (In Russian)

17. Prokop'yev K. Vliyaniye tatar-musul'man na chuvash [The Influence of Muslim Tatars on the Chuvash] Chicherina S. U Privolzhskikh inorodtsev: Putevyye zametki [Visiting 
the Non-Slavic Peoples Living in the Volga Region: Travel Notes]. Saint Petersburg: Tip. V.Ya. Mil'shteina, 1905. - S. 142-145. (In Russian)

18. Rubruk Ghil'om de. Puteshestviye v Vostochnyye strany [Journey to the East] Karpini Dzhovanni del' Plano. Istoriya mongalov [History of the Mongals]. Rubruk Ghil'om de. Puteshestviye $v$ Vostochnyye strany [Journey to the East]. Polo Marko. Kniga [Book]. Moscow: Mysl', 1997. - S. 88-189. (In Russian)

19. Salmin A.K. Prazdniki, obryady i verovaniya chuvashskogo naroda [Holidays, Rituals and Beliefs of the Chuvash People]. Cheboksary: Chuvash. kn. izd-vo, 2016. - 688 s., ill. (In Russian)

20. Semenova T.V. Obryadovyi kalendar" chuvashei $v$ etnokontaktnykh s tatarami raionakh [The Ritual Calendar the Chuvash in the Areas of Their Contct with Tatars]. Saint Petersburg: LEMA, 2015. - 145 s.

21. Favero-Dumenzhu M. Pervoye pis'mo khana Berke sultanu Beibarsu po mamlyukskim istochnikam (661/1263 g.) [The First Letter of Berke Khan to Sultan Beibarsu according to Mamluk Sources (661/1263)] Zolotoordynskaya tsivilizatsiya [The Golden Horde's Civilization]. Vyp. 4. Kazan: II AN RT, 2011. - S. 101-113. (In Russian)

22. Khisamitdinova F.G. Mifologhicheskii slovar' bashkirskogo yazyka [Mythological Dictionary of the Bashkir Language]. Moscow: Nauka, 2010. - 455 s. (In Russian)

23. Ennuveiri Shykhabeddin. Kratkii predel neobkhodimosti po chasti nauki blagovospitannosti [Absolute Necessities in the Science of Good Breeding] Sbornik materialov, otnosyashchikhsya $k$ istorii Zolotoi Ordy [Collection of Materials Relating to the History of the Golden Horde].V. I. Saint Petersburg: S.G. Stroganov, 1884. - S. 128-171. (In Russian)

24. Yagafova Ye.A. Relighioznyye praktiki etnokonfessional'nykh grupp chuvashei [Religious Practices of the Chuvash Ethno-Religious Groups] Etnograficheskoye obozreniye [Ethnographic Review]. 2015, no. 5. - S. 3-18. (In Russian)

25. Arik Durmus. Islam among the Chuvashes and its Role in the Change of Chuvash Ethnicity Journal of Muslim Minority Affairs, Vol. 27, no. 1, 2007. - P. 37-54. 